\title{
MISKONSEPSI KONSEP ARCHAEBACTERIA DAN EUBACTERIA
}

\author{
Fina Nurul Khotimah, Meiry Fadilah Noor, Nengsih Juanengsih \\ Pendidikan Biologi FITK UIN Syarif Hidayatullah, ipinkiw@gmail.com
}

\begin{abstract}
The aims of this research was to elicit students' misconceptions on the concept of Archaebacteria and Eubacteria. A diagnostic test of multiple choice with open reasoning was used to identify the misconceptions. The test was administered to 72 grade $\mathrm{X}$ students of a public Islamic school (Madrasah Aliyah Negeri) in Jakarta. As a result of the analysis, it was found that $19 \%$ of the students had misconceptions on the concept of Archaebacteria and Eubacteria, was 19\%, whereas students who had no understanding was $61 \%$. Students' misconceptions was found more "spesific misconceptions" category than "partial understanding with spesific misconceptions" category. Students' who had misconceptions was said that Prokaryots's disadvantages was more than their advantages.
\end{abstract}

Keywords: specific misconception, open-ended response, cognitive skill

\begin{abstract}
Abstrak
Penelitian ini bertujuan untuk mengidentifikasi miskonsepsi siswa pada konsep Archaebacteria dan Eubacteria. Penelitian ini menggunakan metode survei dengan instrumen berupa pilihan ganda beralasan terbuka sebagai alat ukur. Unit analisis dalam penelitian adalah siswa MAN kelas X berjumlah 72 orang. Hasil analisis ditemukan ketidakpahaman pada konsep Archaebacteria dan Eubacteria (61\%) yang mendominasi kategori lainnya. Sedangkan kategori Paham konsep dan Miskonsepsi hanya sebesar 19\% dan $20 \%$. Miskonsepsi yang dialami siswa dari hasil diagnosa alasan terbuka menunjukkan lebih banyak miskonsepsi utuh dibandingkan dengan miskonsepsi sebagian. Miskonsepsi utuh teridentifikasi dengan siswa beranggapan bahwa bakteri lebih banyak menimbulkan kerugian daripada keuntungan bagi manusia dan lingkungan.
\end{abstract}

Kata Kunci: miskonsepsi utuh, alasan terbuka, kemampuan kognitif

\section{PENDAHULUAN}

Siswa memiliki kemampuan alami untuk berpikir dengan membuat berbagai hubungan dalam mengenali objek tertentu (Krebs, 1999). Begitu pula dalam mempelajari ilmu pengetahuan. Konstruk konsep pengetahuan dilakukan dengan menghubungkan pengetahuan yang didapatkan sehari-hari dengan pengetahuan baru saat belajar di sekolah (Allen, 2010). Namun dalam pembentukan pengetahuan tidak sepenuhnya utuh dibentuk. Hal ini dikarenakan kemampuan siswa terbatas atau bercampur dengan gagasan lain yang kebetulan dialami. Pengetahuan tersebut terus berkembang dengan dipengaruhi oleh pengalaman kognitif dan mental (Suparno, 2005).

Pengalaman kognitif dan mental yang didapat secara utuh, akan menghasilkan perkembangan pengetahuan siswa yang baik dengan memahami konsep tersebut secara benar dan utuh. Sebagaimana pernyataan Abraham et. al. (1992) yang menyebutkan bahwa siswa dalam memahami konsep dapat memahami secara utuh/ lengkap dan dapat pula memahami konsep hanya sebagian saja.

Jika siswa tidak berhasil membuat hubungan yang benar antara awal pengalaman hidup mereka (prakonsepsi) yang dimiliki dengan informasi baru yang diberikan guru, maka akan terbentuk pemahaman yang salah (Mintzer et al., 2005). Pemahaman yang tidak tepat terhadap suatu konsep serta berbeda dengan konsepsi ahli disebut sebagai miskonsepsi (Tekkaya, 2002).

Siswa dengan prakonsepsi kembali mempertahankan pemahaman konsep awalnya dan menempatkan konsep barunya dalam struktur kognitifnya secara terpisah (Barke, 2009). Miskonsepsi yang sudah terbentuk lebih dahulu bersifat sangat kuat dan kukuh, serta sulit untuk dihilangkan dalam pembelajaran formal (National Science Teachers Association, 2013). Dengan demikian, diperoleh pengetahuan dengan miskonsepsi siswa yang utuh akibat dari prakonsepsi yang salah. Namun ada pula miskonsepsi dengan pemahaman sebagian akibat dari ketidakberhasilan dalam membuat hubungan yang benar antara prakonsepsi dengan informasi baru. Seperti Abraham et al. (1992) yang membagi kategori miskonsepsi menjadi miskonsepsi utuh (spesific misconception) dan paham sebagian dengan miskonsepsi (partial understanding with spesific misconception).

Siswa yang mengalami kesulitan dalam mempelajari biologi bisa disebabkan dari kerumitan konsep, istilah ataupun pengintegrasian konsep dari 
skala mikroskopis ke makroskopis (National Science Teachers Association, 2013). Kesulitan belajar siswa dalam suatu konsep dapat ditandai dengan rendahnya hasil belajar siswa (Sabri, 2007). Seperti hasil penelitian di salah satu sekolah MAN wilayah Tangerang didapatkan informasi bahwa rata-rata nilai formatif paling rendah pada konsep Archaebacteria dan Eubacteria dibandingkan dengan konsep lain (Sapuroh, 2010).

Begitu pula dari hasil studi Tarwoko (2005) di salah satu SMAN Sragen yang menemukan miskonsepsi siswa pada konsep bakteri dalam setiap subkonsep yang diujikan. Siswa tersebut mengalami miskonsepsi mengenai organisasi, bentuk, struktur, cara hidup, reproduksi, klasifikasi dan peranan dari bakteri. Padahal konsep tersebut dianggap penting, karena Archaebacteria dan Eubacteria termasuk dalam kelompok prokariot yang memiliki peran penting dalam lapisan kehidupan, khususnya untuk perkembangan penelitian dan teknologi (Campbell et al. 2009).

Berbagai tehnik dipakai untuk pendeteksian gejala miskonsepsi. Macam-macam teknik yang digunakan seperti wawancara, peta konsep, tes esai, tes pilihan ganda dengan alasan, diskusi dalam kelas, serta praktikum dengan disertai tanya jawab (Suparno, 2005). Identifikasi miskonsepsi tes pilihan ganda dengan reasoning terbuka memiliki keunggulan dalam mendeteksi miskonsepsi siswa, karena guru dapat melihat pemahaman siswa, dapat meminimalisir jawaban tebakan siswa dan dapat menentukan tipe kesalahan siswa dalam suatu konsep pemahaman siswa dapat terlihat berdasarkan jawaban yang dipilih (Depdiknas, 2007). Keberhasilan Tarwoko (2005) dalam menggali profil miskonsepsi siswa dengan tes pilihan ganda beralasan terbuka di salah satu Sekolah Menengah Atas Negeri wilayah Sragen, menjadi salah satu tujuan untuk mengidentifikasi miskonsepsi yang terdapat di salah satu Madrasah Aliyah Negeri Jakarta Selatan.

Identifikasi miskonsepsi didasari pada lima kategori yang telah dilakukan oleh penelitian sebelumnya (Abraham et al. 1992; Calik \& Ayas, 2005). Pengukuran miskonsepsi siswa dapat dilakukan dengan jawaban essai, sehingga dapat ditentukan kategori pemahaman siswa pada kepahaman (Understanding), tidak paham (lack of knowledge), dan miskonsepsi sebagian atau miskonsepsi utuh terhadap konsep.

\section{METODE PENELITIAN}

Penelitian ini menggunakan metode kualitatif berbentuk studi kasus (case study). Penelitian studi kasus diarahkan untuk menghimpun data, mengambil makna, serta memperoleh pemahaman (Syaodih, 2012), sehingga didapatkan kesimpulan terhadap kasus tersebut. Kasus dalam penelitian ini yaitu rendahnya hasil belajar siswa di salah satu MAN wilayah Jakarta pada konsep Archaebacteria dan Eubacteria. Rendahnya hasil belajar tersebut ditelusuri tingkat pemahaman siswa dalam menerima informasi pengetahuan berdasarkan empat kategori pemahaman. Tes yang digunakan dalam penelusuran ini berupa tes pilihan ganda beralasan terbuka dan diagnosis berupa wawancara.

Populasi dalam penelitian ini adalah siswa di salah satu MAN Jakarta. Unit analisis yang diteliti berjumlah 72 orang siswa dari dua kelas yang diambil secara purposive sampling berdasarkan kehomogenan kemampuan kognitif dan pengajar yang sama.

Pengumpulan data dilakukan dengan dua tahapan yaitu tes Pilihan Ganda Beralasan Terbuka serta wawancara diagnosa. Istilah tes pilihan ganda beralasan terbuka disebut pula oleh Calik \& Ayas (2005) sebagai two-tier question, dikarenakan soal terdiri dari dua bagian yaitu pilihan ganda dan alasan jawaban yang diisi secara terbuka (openended response). Sedangkan wawancara diagnosa bertujuan untuk diperolehnya informasi lebih lanjut mengenai miskonsepsi dan konsepsi yang dimiliki siswa setelah dilakukannya tes. Teknik wawancara yang digunakan dengan teknik wawancara semi structured, yaitu mengacu pada pedoman serta pertanyaan bebas sesuai dengan perkembangan jawaban siswa (Arikunto, 2010).

Instrumen tes Pilihan ganda dibuat dengan empat pilihan jawaban dengan peluang menerka jawaban sekitar 25\% (Sukardi, 2008). Penyusunan soal ditentukan berdasarkan Standar Kompetensi, Kompetensi Dasar, dan Indikator pembelajaran; penentuan tujuan diagnosis; penyusunan kisi instrumen; penyusunan draft instrumen soal; review dan revisi soal; uji coba soal; analisa soal; serta perakitan soal (Widdiharto, 2008). Soal yang disusun berjumlah 38 soal yang telah direview oleh dua ahli bidang Biologi. Selanjutnya diuji coba ke siswa yang telah mendapatkan konsep tersebut dan memiliki kesetaraan kognitif dengan siswa yang dijadikan sampel pengambilan data. Setelah diujicobakan, selanjutnya diuji kevalidan dengan rumus koefisien korelasi biserial rumus koefisien korelasi biserial, dan uji reabilitas mengacu pada 
nilai product moment. Hasil ujicoba dan analisa soal didapatkan 18 soal dalam 7 subkonsep yang digunakan sebagai instrumen penentuan miskonsepsi dengan alasan terbuka. Butir soal beserta subkonsep dapat dilihat pada Tabel 1.

Adapun teknik analisis jawaban dari tes pilihan ganda beralasan yang digunakan yaitu mengacu pada teknik yang dilakukan Muammer Calik dan Alipasa Ayas. Tekniknya yaitu dengan mengkombinasikan pilihan jawaban siswa dengan alasannya, sehingga jawaban pada pilihan pertama menjadi bentuk uraian yang disertai dengan jawaban alasan terbuka atau dapat dikatakan serupa dengan jawaban pada soal uraian. kombinasi jawaban tersebut selanjutnya dikategorikan dalam lima derajat pemahaman (Calik \& Ayas, 2005). Pengelompokkan derajat pemahaman siswa yang dimaksud terdapat pada Tabel 2.

Tabel 1. Subkonsep Soal Tes Diagnostik

\begin{tabular}{|c|c|c|c|}
\hline & SubKonsep & $\begin{array}{l}\text { Nomor } \\
\text { Soal }\end{array}$ & Indikator Soal \\
\hline 1. & $\begin{array}{l}\text { Perbedaan sel eukariotik } \\
\text { dan prokariotik }\end{array}$ & 1 & Menunjukkan ciri sel prokariot pada gambar \\
\hline \multirow{4}{*}{2.} & \multirow{4}{*}{$\begin{array}{l}\text { Ciri dan fungsi bagian- } \\
\text { bagian sel Prokariotik }\end{array}$} & 3 & Menyimpulkan fungsi endospora pada bakteri \\
\hline & & 4 & Menyebutkan zat utama penyusun dinding sel bakteri \\
\hline & & 2 & $\begin{array}{l}\text { Membandingkan ukuran sel bakteri dengan sel/bagian sel makhluk hidup } \\
\text { lainnya }\end{array}$ \\
\hline & & 5 & $\begin{array}{l}\text { Membandingkan organel sel yang berfungsi sebagai tempat fotosintesis pada } \\
\text { sel prokariotik dan eukariotik }\end{array}$ \\
\hline 3. & $\begin{array}{l}\text { Habitat, Populasi, dan jenis } \\
\text { koloni Organisme } \\
\text { Prokariotik }\end{array}$ & 6 & Menyebutkan bahwa tubuh manusia adalah salah satu habitat dari bakteri \\
\hline \multirow[t]{2}{*}{4.} & $\begin{array}{l}\text { Perkembangbiakan dan } \\
\text { pertumbuhan Organisme } \\
\text { Prokariotik }\end{array}$ & 18 & Menjelaskan pengaruh antibiotik terhadap pertumbuhan bakteri gram positif \\
\hline & & 7 & Menjelaskan cara memperoleh makanan pada bakteri \\
\hline \multirow[t]{4}{*}{5 . } & $\begin{array}{l}\text { Pengelompokkan organisme } \\
\text { Prokariotik berdasarkan }\end{array}$ & 9 & $\begin{array}{l}\text { Mengkategorikan jenis bakteri berdasarkan koloni yang tumbuh pada media } \\
\text { cair. }\end{array}$ \\
\hline & kebutuhan oksigen, jenis & 10 & Menyimpulkan kebutuhan bakteri akan oksigen berdasarkan pada gambar \\
\hline & mendapatkan energi & 8 & Membedakan jenis bakteri berdasarkan kebutuhan oksigennya \\
\hline & & 11 & Membedakan ciri mendasar antara bakteri dan ganggang hijau biru \\
\hline \multirow[t]{3}{*}{6.} & Ciri dan karakteristik & 12 & $\begin{array}{l}\text { Menyebutkan perbedaan dasar antara kelompok Archaebacteria dengan } \\
\text { Eubacteria }\end{array}$ \\
\hline & Archaebacteria & 13 & $\begin{array}{l}\text { Menyebutkan perbedaan sel antara kelompok Archaebacteria dengan } \\
\text { Eubacteria }\end{array}$ \\
\hline & & 17 & $\begin{array}{l}\text { Menunjukkan usaha manusia yang dilakukan untuk menghindari peran negatif } \\
\text { bakteri }\end{array}$ \\
\hline \multirow[t]{3}{*}{7.} & Peranan positif dan negatif & 14 & Menjelaskan peranan positif bakteri bagi tubuh manusia \\
\hline & & 15 & Menyimpulkan peran bakteri bagi ekosistem \\
\hline & & 16 & Menunjukkan peranan negatif bakteri pada kesehatan manusia \\
\hline
\end{tabular}


Tabel 2. Derajat Pemahaman Siswa berdasarkan Kriteria Jawaban

\begin{tabular}{|c|c|c|}
\hline Derajat Pemahaman & Kode & Kriteria Jawaban \\
\hline Paham Konsep & PK & Jawaban menunjukkan komponen yang sesuai dengan konsep secara lengkap \\
\hline Paham Sebagian Konsep & PS & $\begin{array}{l}\text { Jawaban menunjukkan satu atau beberapa komponen yang sesuai dengan konsep, } \\
\text { tetapi belum lengkap }\end{array}$ \\
\hline $\begin{array}{l}\text { Paham Sebagian konsep disertai } \\
\text { Miskonsepsi }\end{array}$ & PSM & $\begin{array}{l}\text { Jawaban menunjukkan adanya pemahaman pada suatu konsep tetapi disertai } \\
\text { dengan pernyataan yang mengandung kesalahpahaman. }\end{array}$ \\
\hline Miskonsepsi utuh & M & Jawaban mengandung ketidaklogisan atau informasi yang salah \\
\hline Tidak Paham Konsep & TPK & $\begin{array}{l}\text { Mengulangi pertanyaan; jawaban tidak relevan atau jawaban tidak tuntas; atau tidak } \\
\text { dijawab }\end{array}$ \\
\hline
\end{tabular}

\section{HASIL DAN PEMBAHASAN}

Soal tes terbagi menjadi 7 subkonsep dengan soal sebanyak 18 butir yang diujikan terhadap 72 siswa kelas X. Hasil penelitian ini didapatkan dari data tes dan wawancara. Hasil analisis jawaban siswa pada soal pilihan ganda beralasan terbuka disederhanakan menjadi 3 kategori yaitu pada Paham (P dan PS), Miskonsepsi (PKM dan M), serta Tidak Paham Konsep. Adapun hasil tersebut pada Gambar 1.

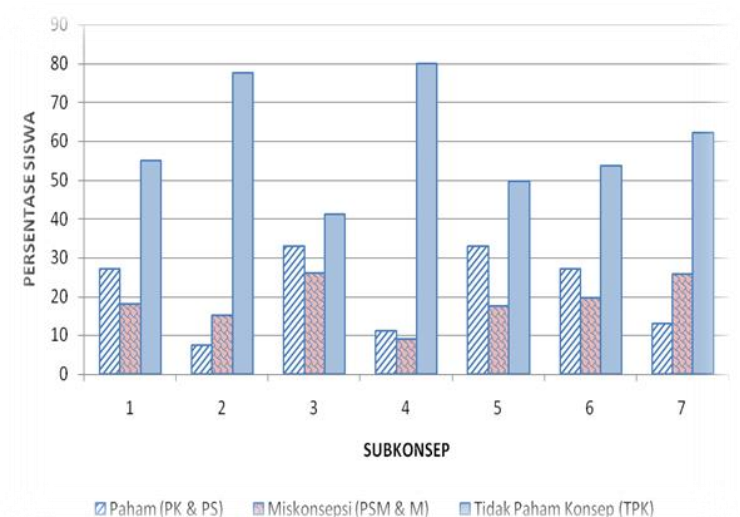

Gambar 1. Perbandingan Persentase dalam Tiga Kategori pada Tiap Subkonsep

Gambar 1 menunjukkan bahwa setiap subkonsep siswa lebih banyak yang tidak paham daripada paham dan miskonsepsi. Ketidakpahaman tersebut mencapai lebih dari 50\%. Ketidakpahaman yang paling mendominasi pada subkonsep Perkembangbiakan dan Pertumbuhan, serta diikuti Ciri dan Fungsi Bagian-bagian dari Sel Prokariotik. Sedangkan kepahaman dan kemiskonsepsian hanya maksimal berkisar 30\% dengan subkonsep Habitat, Populasi, dan Jenis Koloni, serta Peranan Positif dan Negatif Organisme Prokariotik yang mendominasi kategori Miskonsepsi. Dominansi dari ketujuh subkonsep tersebut bila dilihat perbutir soal dengan lima kategori pemahaman menunjukkan adanya dominasi kategori persoal. Adapun sebaran persentase dari tiap kategori tersebut pada Tabel 3. Butir soal nomor 1 mendominasi kepahaman siswa dengan persentase sebesar $26 \%$. Siswa yang paham sebagian dari konsep dengan pencapaian 34\% terdapat pada butir soal nomor 10. Sedangkan miskonsepsi tertinggi pada butir soal nomor 17 dengan ketidakpahaman lebih rendah dari miskonsepsi $(35<25)$. Soal nomor 4 memiliki persentase mendekati $100 \%$ pada ketidakpahaman. Namun bila dilihat dari rata-rata kepahaman secara utuh sebesar $6 \%$ dan miskonsepsi murni hanya 13\%. Hal ini menunjukkan bahwa kepahaman dan kemiskonsepsian yang dipecah dengan kategori sebagian, tetap tidak menunjukkan persentase yang tinggi terhadap kepahaman maupun kemiskonsepsian. Temuan yang didapat dari analisis ini menunjukkan ketidakpahaman di tiap butir soal dalam tiap subkonsep, kecuali pada soal nomor 17.

Tabel 3. Persentase 5 Kategori Pemahaman Siswa Setiap Butir Soal

\begin{tabular}{|c|c|c|c|c|c|c|}
\hline \multirow{2}{*}{$\begin{array}{c}\text { Sub- } \\
\text { konsep }\end{array}$} & \multirow{2}{*}{$\begin{array}{l}\text { Butir } \\
\text { Soal }\end{array}$} & \multicolumn{5}{|c|}{ Kategori Tingkat Pemahaman } \\
\hline & & PK & PS & PSM & $\mathbf{M}$ & TPK \\
\hline \multirow[t]{2}{*}{1} & 1 & 26 & 2 & 3 & 15 & 54 \\
\hline & 2 & 4 & 6 & 7 & 7 & 76 \\
\hline \multirow{3}{*}{2} & 3 & 0 & 12 & 13 & 6 & 69 \\
\hline & 4 & 3 & 1 & 0 & 6 & 90 \\
\hline & 5 & 3 & 1 & 4 & 17 & 75 \\
\hline 3 & 6 & 1 & 33 & 18 & 8 & 40 \\
\hline \multirow[t]{2}{*}{4} & 18 & 1 & 11 & 1 & 8 & 79 \\
\hline & 7 & 6 & 20 & 3 & 14 & 57 \\
\hline \multirow{4}{*}{5} & 8 & 18 & 15 & 8 & 3 & 56 \\
\hline & 9 & 11 & 17 & 7 & 19 & 46 \\
\hline & 10 & 11 & 34 & 8 & 8 & 39 \\
\hline & 11 & 10 & 10 & 6 & 11 & 63 \\
\hline \multirow{3}{*}{6} & 12 & 1 & 33 & 14 & 8 & 44 \\
\hline & 13 & 0 & 3 & 8 & 15 & 74 \\
\hline & 14 & 0 & 13 & 0 & 13 & 74 \\
\hline \multirow{3}{*}{7} & 15 & 1 & 6 & 0 & 25 & 68 \\
\hline & 16 & 0 & 11 & 1 & 24 & 64 \\
\hline & 17 & 7 & 26 & 7 & 35 & 25 \\
\hline \multicolumn{2}{|c|}{ Rata-rata } & 6 & 14 & 6 & 13 & 61 \\
\hline
\end{tabular}


Butir soal yang memiliki persentase miskonsepsi mencapai lebih dari $10 \%$ berjumlah 13 soal. Penyebaran miskonsepsi dapat diketahui siswa yang dikelompokkan berdasarkan tingkatan tinggi, sedang, dan rendah. Pengelompokan kognitif siswa dilakukan dengan cara mengurutkan nilai siswa pada instrumen pilihan ganda dari yang terendah sampai tertinggi. Selanjutnya siswa dikelompokkan menjadi tiga kelompok berdasarkan nilai rataratanya. Kemudian persentase miskonsepsi dihitung pada masing-masing kelompok siswa pada setiap butir soal. Hasil dari analisis ini dengan kelompok siswa yang dominan dalam persentase miskonsepsi, dijadikan sebagai sampel wawancara diagnostik di setiap butir soal.

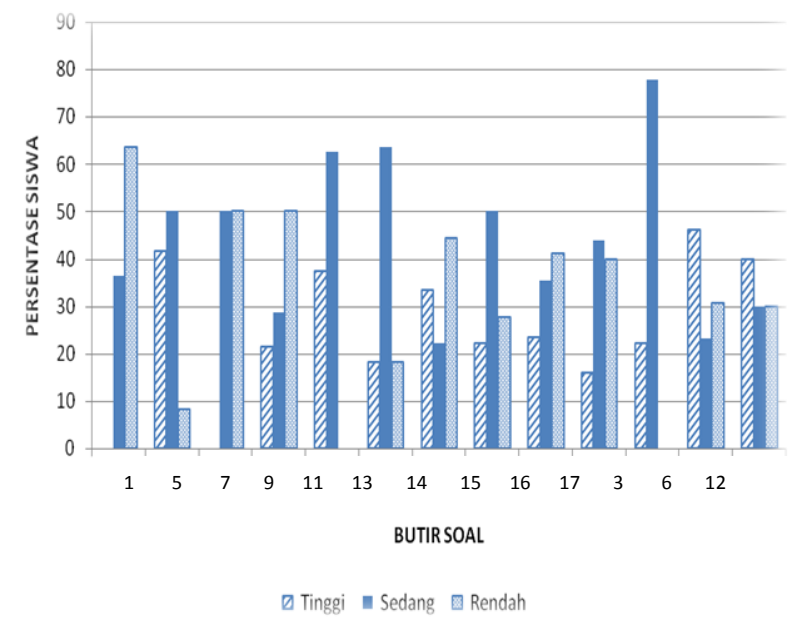

Gambar 2. Perbandingan Kelompok Kognitif Siswa yang Menyebabkan Adanya Miskonsepsi

Gambar 2 memperlihatkan kelompok siswa yang memberi sumbangsih persentase pada miskonsepsi terbesar pada setiap butir soal. Penilaian instrumen maksimal pada skala 10. Pada kelompok kognitif sedang (rentangan nilai 4,2-6,6) lebih mendominasi dalam memunculkan miskonsepsi. Hal ini terlihat dari bar pada butir soal nomor 5, 11, 13, 15, 17, dan 3. Sedangkan kelompok rendah mendominasi persentase miskonsepsi pada butir soal 1, 9, 14, 16. Kelompok tinggi juga mendominasi dalam miskonsepsi pada butir soal 6 dan 12. Sedangkan miskonsepsi pada butir 7, persentasenya terbagi rata pada kelompok siswa sedang dan rendah. Namun pada soal nomor 17 dengan persentase miskonsepsi tertinggi, didapatkan dari kelompok kognitif tinggi dan sedang. Berikut ini data pernyataan jawaban dan alasan siswa Kategori Miskonsepsi per Subkonsep yang dianalisis dari keseluruhan pernyataan setiap jengjang kognitif.

\section{Subkonsep Perbedaan Sel Prokariotik dan Eukariotik}

Subkonsep ini diwakili oleh soal nomor 1 dengan indikator soal mengenai "Struktur Anatomis Sel Prokariot". Persentase siswa yang miskonsepsi pada subkonsep ini yakni sebesar $18 \%$. Kategori ini didominasi oleh siswa yang memiliki miskonsepsi utuh (M).

Tabel 4. Miskonsepsi Utuh pada Butir Soal 1

\begin{tabular}{|c|c|}
\hline Jawaban Siswa & $\begin{array}{c}\text { Jumlah } \\
\text { Siswa } \\
\end{array}$ \\
\hline 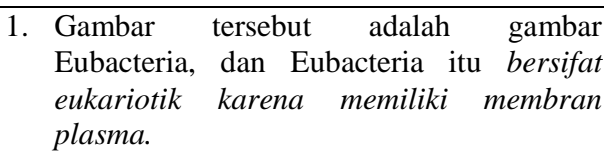 & 2 \\
\hline $\begin{array}{l}\text { 2. Organisme ini bersifat eukariotik karena } \\
\text { memiliki membran plasma, sedangkan } \\
\text { prokariotik tidak memiliki membran } \\
\text { plasma. }\end{array}$ & 1 \\
\hline $\begin{array}{l}\text { 3. Organisme ini bersifat eukariotik karena } \\
\text { memiliki dinding sel. Karena dalam } \\
\text { struktur bakteri terdapat dinding sel. }\end{array}$ & 2 \\
\hline $\begin{array}{l}\text { 4. Organisme ini bersifat eukariotik karena } \\
\text { memiliki membran plasma, karena } \\
\text { eukariotik merupakan bagian dari } \\
\text { eubacteria. }\end{array}$ & 1 \\
\hline $\begin{array}{l}\text { 5. Organisme ini bersifat eukariotik karena } \\
\text { memiliki dinding sel, karena organisme } \\
\text { memiliki peptidoglikan di dinding sel. }\end{array}$ & 2 \\
\hline $\begin{array}{l}\text { 6. Organisme ini bersifat eukariotik karena } \\
\text { memiliki membran plasma, karena lapisan } \\
\text { ke-3 bakteri adalah membran plasma } \\
\text { (eukariotik). }\end{array}$ & 1 \\
\hline $\begin{array}{l}\text { 7. Organisme ini bersifat prokariotik karena } \\
\text { dapat melakukan reproduksi secara } \\
\text { aseksual, karena memiliki pili yang } \\
\text { fungsinya untuk menempel pada sel inang } \\
\text { dan juga dia untuk jembatan konjugasi. } \\
\text { Bakteri ini juga memiliki membran plasma } \\
\text { dan dinding sel dan sebenarnya juga } \\
\text { bakteri ini memiliki membran inti. }\end{array}$ & 1 \\
\hline $\begin{array}{l}\text { 8. Organisme ini bersifat eukariotik karena } \\
\text { memiliki dinding sel, kapsid, dll untuk } \\
\text { melindungi bagian yang di dalam. }\end{array}$ & 1 \\
\hline
\end{tabular}

Pernyataan siswa yang miskonsepsi memberikan alasan bahwa gambar pada soal tersebut termasuk dalam kelompok eukariotik. Konsepsi siswa pada butir ini adalah organisme pada gambar merupakan Eubacteria yang termasuk organisme eukariotik karena memiliki membran plasma, sedangkan organisme prokariotik adalah organisme yang tidak memiliki membran plasma.

Menurut teori dalam pustaka, bakteri merupakan organisme prokariotik dengan ciri khas selnya yang tidak memiliki membran inti (Pujiyanto, 2012). Miskonsepsi responden terhadap konsep struktur anatomis sel bakteri ini kemungkinan disebabkan responden tidak memiliki pengetahuan prasarat (konsep sel secara umum) pada saat mengikuti pembelajaran konsep struktur anatomis sel bakteri (Tarwoko, 2005). Responden 
yang tidak memahami konsep dasar tentang sel khususnya mengenai keberadaan membran baik membran inti maupun membran sel, dapat menemui kesalahan saat mempelajari struktur sel yang khusus seperti pada sel bakteri. Apabila telah memiliki pengetahuan prasarat, maka pada saat mempelajari konsep-konsep yang lebih rumit, sistem memori tinggal menyambungkan pada struktur kognitif yang telah ada di dalam otak (Tarwoko, 2005).

\section{Subkonsep Ciri dan Fungsi bagian-bagian Sel Prokariot}

Subkonsep kedua merupakan konsep lanjutan dari subkonsep pertama, yakni mengenai "Ciri dan fungsi bagian-bagian sel prokariot". Persentase siswa yang miskonsepsi pada subkonsep ini sebesar $15 \%$ yang didominasi oleh miskonsepsi sebagian. Subkonsep ini diwakili oleh butir soal nomor 2, 3, 4, dan 5. Keempat butir soal, persentase tinggi terdapat pada butir 3 dan 5 (Tabel 3).

Pada butir soal nomor 3, jumlah siswa yang pernyataannya termasuk Paham Sebagian dengan Miskonsepsi (PSM) lebih banyak dibandingkan dengan yang Miskonsepsi utuh (M). Siswa yang jawabannya termasuk PSM tersebut telah mengetahui bahwa endospora bukan alat perkembangbiakan bakteri. Namun siswa menganggap bahwa endospora merupakan bagian dari bakteri yang dapat melindungi tubuhnya saat cuaca ekstrim (Tabel 5).

Secara teori, endospora adalah struktur pertahanan didalam sel bakteri yang dibentuk saat kondisi tidak menguntungkan (Pujiyanto, 2012). Penggunaan kata melindungi dalam menjelaskan fungsi endospora menyiratkan adanya kesalahpahaman siswa. Kata melindungi bisa jadi diartikan siswa sebagai fungsi pertahanan endospora dari luar. Jika hal ini benar, kemungkinan siswa telah mengalami miskonsepsi yang disebabkan karena intuisi siswa yang salah terhadap konsep endospora. Pemikiran intuitif dapat berasal dari pengalaman akan benda atau kejadian yang dialami, sehingga saat berhadapan dengan konsep pelajaran pemikiran ini akan terbawa (Suparno, 2005). Setelah ditelusuri melalui wawancara, siswa dengan konsepsi tersebut memang beranggapan bahwa endospora adalah alat pelindung luar yang melapisi bakteri dari kondisi tidak menguntungkan contohnya suhu ekstrim.

Butir soal 5 merupakan indikator pada subkonsep 2 mengenai "Organel tempat terjadinya fotosintesis pada sel bakteri". Temuan miskonsepsi dari indikator ini yaitu "Siswa menganggap bahwa proses fotosintesis bakteri terjadi pada kloroplas". Berdasarkan buku pembelajaran Biologi bakteri yang melakukan fotosintesis (autotrof) melangsungkan prosesnya pada organel khusus yang mirip dengan kloroplas yang bernama lembar tilakoid, bukan pada kloroplas (Widiyati, 2009).

Tabel 5. Alasan Siswa sebagai Pernyataan yang Miskonsepsi pada Subkonsep Kedua

\begin{tabular}{|c|c|c|}
\hline $\begin{array}{c}\text { No } \\
\text { Soal } \\
\end{array}$ & Jawaban Siswa & $\begin{array}{c}\text { Jumlah } \\
\text { Siswa }\end{array}$ \\
\hline \multirow{3}{*}{3} & $\begin{array}{l}\text { Endospora bukan salah satu dari cara- } \\
\text { cara perkembangbiakan bakteri. } \\
\text { Endospora yaitu pembentukan sintesis } \\
\text { pada dinding sel. }\end{array}$ & 1 \\
\hline & $\begin{array}{l}\text { Endospora bukan salah satu cara } \\
\text { perkembangbiakan pada bakteri, karena } \\
\text { endospora ialah alat untuk melindungi } \\
\text { bakteri dari cuaca ekstrim. }\end{array}$ & 7 \\
\hline & $\begin{array}{l}\text { Endospora bukan merupakan salah satu } \\
\text { cara perkembangbiakan pada bakteri } \\
\text { karena endospora tempat berkembang } \\
\text { biak dengan cara fragmentasi, membelah } \\
\text { diri, dan tunas. }\end{array}$ & 1 \\
\hline \multirow{7}{*}{7} & $\begin{array}{l}\text { Proses fotosintesis bakteri terjadi pada } \\
\text { sitoplasma, karna } \\
\text { mengandung klorofil. }\end{array}$ & 1 \\
\hline & $\begin{array}{l}\text { Proses fotosintesis bakteri terjadi pada } \\
\text { kloroplas, karena kloroplas bakteri } \\
\text { mengandung klorofil untuk proses } \\
\text { fotosintesis. }\end{array}$ & 3 \\
\hline & $\begin{array}{l}\text { Proses fotosintesis bakteri terjadi pada } \\
\text { sitoplasma, karna sitoplasma tempat } \\
\text { reaksi kimia dan metabolisme sel, karena } \\
\text { bakteri tidak punya klorofil untuk } \\
\text { berfotosintesis sedangkan dinding sel } \\
\text { hanya sebagai tempat pelindung dan } \\
\text { pembentuk tubuh bakteri. }\end{array}$ & 1 \\
\hline & $\begin{array}{l}\text { Proses fotosintesis bakteri terjadi pada } \\
\text { dinding sel, karena cahaya hanya dapat } \\
\text { sampai di dinding sel. }\end{array}$ & 1 \\
\hline & $\begin{array}{l}\text { Proses fotosintesis bakteri terjadi pada } \\
\text { kloroplas, yang didalamnya terdapat } \\
\text { DNA dan RNA bakteri yang membantu } \\
\text { untuk membuat makanan. }\end{array}$ & 2 \\
\hline & $\begin{array}{l}\text { Proses fotosintesis bakteri terjadi pada } \\
\text { sitoplasma, karna sitoplasma tempat } \\
\text { organel sel/ metabolisme sel. }\end{array}$ & 1 \\
\hline & $\begin{array}{l}\text { Proses fotosintesis bakteri terjadi pada } \\
\text { dinding sel, karena bakteri menempel } \\
\text { pada dinding sel. }\end{array}$ & 3 \\
\hline
\end{tabular}

\section{Subkonsep Habitat Organisme Prokariotik}

Subkonsep ketiga hanya diwakili oleh butir soal 6. Butir ini berisi indikator mengenai tubuh manusia sebagai salah satu habitat bagi bakteri. Persentase dari kategori miskonsepsi siswa pada butir ini yaitu 26\%. Pernyataan miskonsepsi di butir ini menunjukkan siswa telah memahami bahwa terdapat bakteri yang dapat tumbuh dalam tubuh manusia. Tetapi, alasan yang diberikan masih mengandung miskonsepsi. Pernyataan miskonsepsinya yaitu sebagian besar menyatakan bahwa "Bakteri dapat tumbuh dan hidup saat berada di dalam sel, jika keluar sel, maka bakteri tidak dapat tumbuh melainkan akan mengkristal". (Tabel 6). 
Tabel 6. Alasan Siswa sebagai Pernyataan yang Miskonsepsi pada Subkonsep 2

\begin{tabular}{lc}
\hline \multicolumn{3}{c}{ Jawaban Siswa } & $\begin{array}{c}\text { Jumlah } \\
\text { Siswa }\end{array}$ \\
\hline Terdapat bakteri yang hidup dan berkembangbiak & \\
dengan baik di dalam tubuh manusia karena & 1 \\
bakteri hanya bisa berkembangbiak dengan & \\
adanya bakteri lain. & \\
Terdapat bakteri yang hidup dan berkembangbiak & \\
dengan baik di dalam tubuh manusia karena ada & \\
bakteri yang transduksi yaitu butuh perantara & 1 \\
untuk berkembang biak, salah satunya di tubuh & \\
manusia & \\
Terdapat bakteri yang hidup dan berkembangbiak & \\
dengan baik di dalam tubuh manusia contohnya & 4 \\
E. Coli dalam proses penyerapan makanan di & \\
usus besar. & \\
Terdapat bakteri yang hidup dan berkembangbiak & \\
dengan baik di dalam tubuh manusia karena & \\
bakteri akan tumbuh dan hidup di dalam sel. dan & 3 \\
bila keluar dari sel, maka bakteri akan & \\
mengkristal dan tidak dapat tumbuh & \\
Terdapat bakteri yang hidup dan berkembangbiak & \\
dengan baik di dalam tubuh manusia karena ada & \\
bakteri yang merugikan dan ada yang & 1 \\
menguntungkan. Sehingga bakteri yang & \\
menguntungkan dapat hidup dan berkembang & \\
baik di dalam tubuh manusia. & \\
Terdapat bakteri yang hidup dan berkembangbiak & \\
dengan baik di dalam tubuh manusia karena & 1 \\
berperan ekresi pada tubuh manusia. & \\
\hline
\end{tabular}

Siswa yang mengalami miskonsepsi tersebut cenderung lebih mengasosiasikan organisme bakteri dengan virus khususnya dalam cara hidupnya. Berdasarkan pustaka, bakteri merupakan anggota dari kingdom Monera yang tersusun atas sel sejati, tidak seperti virus yang tubuhnya bukan merupakan sel. Virus tidak seperti sel karena tidak dapat bereproduksi dan bermetabolisme jika tidak menggunakan energi pada sel hidup organisme lain (Garber, 2002). Temuan miskonsepsi ini mendukung tulisan dalam artikel dari University of Southern California dimana terdapat miskonsepsi yang umum dialami siswa, salah satunya mengenai bakteri adalah virus (American Institute of Biological Sciences, 2002).

\section{Subkonsep Pertumbuhan Organisme Pro- kariotik}

Subkonsep keempat diwakili oleh butir nomor 18. Butir soal ini berisi indikator mengenai pengaruh antibiotik terhadap pertumbuhan bakteri gram positif. Pada butir ini persentase jawaban siswa yang termasuk kategori miskonsepsi dan "paham" sebesar 11\% dan 9\%. Sedangkan 79\% siswa lainnya termasuk kategori "tidak paham konsep".

Soal pada butir ini termasuk soal pada tingkatan kognitif penerapan. Siswa diharuskan memahami pengaruh penerapan antibiotik terhadap bakteri jenis gram positif. Konsep mengenai respon bakteri terhadap antibiotik seharusnya telah tersampaikan pada saat pelaksanaan pembelajaran, sebagaimana dengan jabaran materi yang terdapat pada RPP yang digunakan guru. Akan tetapi siswa dalam menjawab soal pada butir ini, sebagian besar termasuk dalam kategori "tidak memahami konsep". Hal ini dapat disebabkan karena pengetahuan siswa yang kurang mendalam mengenai penerapan antibiotik tersebut. Bisa jadi dalam pembelajaran, guru hanya menyampaikan materi secara garis besarnya saja. Sedangkan, pengetahuan yang sifatnya penerapan memerlukan kegiatan pembelajaran yang bersifat konkret (Zulfiani, dkk., 2009).

\section{Subkonsep Pengelompokkan Organisme Pro- kariotik}

Siswa dalam menjawab soal pada subkonsep kelima ini pernyataan yang termasuk kategori "miskonsepsi" sebesar 18\%. Penyebab miskonsepsi tinggi pada subkonsep ini adalah jawaban siswa pada butir soal nomor 7, 9 dan 11. Pada ketiga butir soal tersebut, siswa yang miskonsepsi sebagian besar memberikan pernyataan jawaban yang termasuk kategori Miskonsepsi secara utuh (M), karena sebagian besar siswa memilih pilihan jawaban yang salah dengan dilengkapi alasan yang salah pula. Adapun alasan yang menjadikan pernyataan sebagai miskonsepsi pada Tabel 7 .

Pada butir nomor 7, terdapat pernyataan miskonsepsi dimana sebagian besar siswa tertukar dalam membedakan cara memperoleh makan antara bakteri autotrof dan bakteri heterotrof. Sebagian besar jawaban siswa yang miskonsepsi menganggap bahwa "Bakteri heterotrof adalah bakteri yang dapat menghasilkan makanannya sendiri". Siswa yang miskonsepsi jelas tertukar antara jenis bakteri heterotrof dan autotrof.

Persentase siswa yang miskonsepsi pada butir soal nomor 9 yakni sebesar 19\%. Pada butir ini, siswa harus mengidentifikasi jenis bakteri yang tumbuh pada gambar tabung yang berisi media nutrisi bakteri. Sebagian besar siswa yang memberikan jawaban miskonsepsi menganggap bahwa bakteri anaerob obligat adalah bakteri yang membutuhkan oksigen sehingga tumbuhnya pada media dalam tabung A. Sedangkan konsep yang seharusnya bakteri anaerob adalah bakteri yang tidak membutuhkan oksigen untuk hidup. 
Tabel 7. Alasan Siswa sebagai Pernyataan yang Miskonsepsi pada Subkonsep Kelima

\begin{tabular}{|c|c|c|}
\hline $\begin{array}{c}\text { Soal } \\
\text { Nomor }\end{array}$ & Jawaban Siswa & $\begin{array}{r}\text { Jumlah } \\
\text { siswa }\end{array}$ \\
\hline \multirow{6}{*}{7} & $\begin{array}{l}\text { Bakteri heterotrof tidak mendapatkan makanan dari bahan organik dengan menguraikan sisa tubuh } \\
\text { organisme lain, karena bakteri heterotrof adalah bakteri yang dapat menghasilkan makanannya sendiri. }\end{array}$ & 4 \\
\hline & $\begin{array}{l}\text { Bakteri autotrof tidak mendapatkan energi dari cahaya untuk melakukan fotosintesis karena autotrof tidak } \\
\text { membutuhkan bantuan untuk membuat makanannya sendiri. }\end{array}$ & 2 \\
\hline & $\begin{array}{l}\text { Bakteri autotrof tidak dapat membuat bahan organik sendiri karena autotrof itu dapat membuat makanannya } \\
\text { sendiri, yaitu parasit, patogen, dan saprofit. }\end{array}$ & 1 \\
\hline & $\begin{array}{l}\text { Bakteri autotrof tidak dapat membuat bahan organik sendiri karena bakteri hanya dapat memperoleh } \\
\text { makanan dari fotosintesis dan sisa tubuh organisme lain. }\end{array}$ & 1 \\
\hline & $\begin{array}{l}\text { Bakteri heterotrof tidak mendapatkan makanan dari bahan organik dengan menguraikan sisa tubuh } \\
\text { organisme lain, karena bakteri kebanyakan hidup pada sel inang. Dengan parasit atau merugikan sel inang. }\end{array}$ & 1 \\
\hline & $\begin{array}{l}\text { Bakteri autotrof tidak mendapatkan energi dari cahaya untuk melakukan fotosintesis karena energi dari } \\
\text { cahaya hanya dilakukan untuk cara memperoleh oksigen. }\end{array}$ & 1 \\
\hline \multirow{5}{*}{9} & $\begin{array}{l}\text { Anaerob obligat ada pada tabung A. Anaerob obligat adalah bakteri yang membutuhkan oksigen. Jadi, koloni } \\
\text { bakteri tersebut berkumpul dekat dengan oksigen/ daerah yang di atas. }\end{array}$ & 9 \\
\hline & $\begin{array}{l}\text { Anaerob obligat ada pada tabung } \mathrm{C} \text { dan } \mathrm{D} \text {, karena menunjukkan bahwa terdapat banyak oksigen dan tidak } \\
\text { adanya oksigen. Dan bakteri Anaerob obligat dapat hidup dengan/ tidak dengan oksigen. }\end{array}$ & 1 \\
\hline & $\begin{array}{l}\text { Anaerob obligat ada pada tabung A. Koloni bakteri anaerob obligat hanya bisa hidup di permukaan air } \\
\text { dengan banyak } \mathrm{O}_{2} \text { dan } \mathrm{CO}_{2} \text {. }\end{array}$ & 1 \\
\hline & Anaerob obligat ada pada tabung $\mathrm{C}$ dan $\mathrm{D}$, karena bakteri anaerob obligat hanya bisa hidup melalui oksigen. & 2 \\
\hline & $\begin{array}{l}\text { Anaerob obligat ada pada tabung A. Anaerob obligat adalah bakteri yang hanya bisa hidup jika tanpa adanya } \\
\text { oksigen. Ketika didalam tabung tersebut terisi oksigen maka bakteri-bakteri tersebut akan mati. Masa jenis } \\
\text { bakteri lebih kecil dari masa jenis air, itulah yang menyebabkan bakteri terapung. }\end{array}$ & 1 \\
\hline \multirow{5}{*}{13} & Bakteri hidup bersimbiosis, ganggang biru tidak. Bakteri bersimbiosis karena hidupnya berparasit. & 2 \\
\hline & $\begin{array}{l}\text { Bakteri tidak memiliki membran inti, ganggang biru memiliki membran inti. Karena ciri bakteri adalah sel } \\
\text { prokariotik yang tidak memiliki membran inti. }\end{array}$ & 1 \\
\hline & $\begin{array}{l}\text { Bakteri hidup bersimbiosis, ganggang biru tidak. Bakteri ada yang menguntungkan dan ada yang merugikan } \\
\text { (bersimbiosis) ganggang biru tidak bersimbiosis. }\end{array}$ & 3 \\
\hline & $\begin{array}{l}\text { Bakteri hidup bersimbiosis, ganggang biru tidak. Karena bakteri membutuhkan simbiosis/hubungan antar } \\
\text { makhluk untuk membuat makanan sedangkan ganggang fotosintesis. }\end{array}$ & 1 \\
\hline & $\begin{array}{l}\text { Bakteri dapat melakukan pembelahan sel, ganggang biru tidak. Karena sudah jelas sangat berbeda, bakteri }= \\
\text { hewan, ganggang = tumbuhan. }\end{array}$ & 1 \\
\hline
\end{tabular}

Tabel 8. Alasan Siswa sebagai Pernyataan yang Miskonsepsi pada Subkonsep Keenam

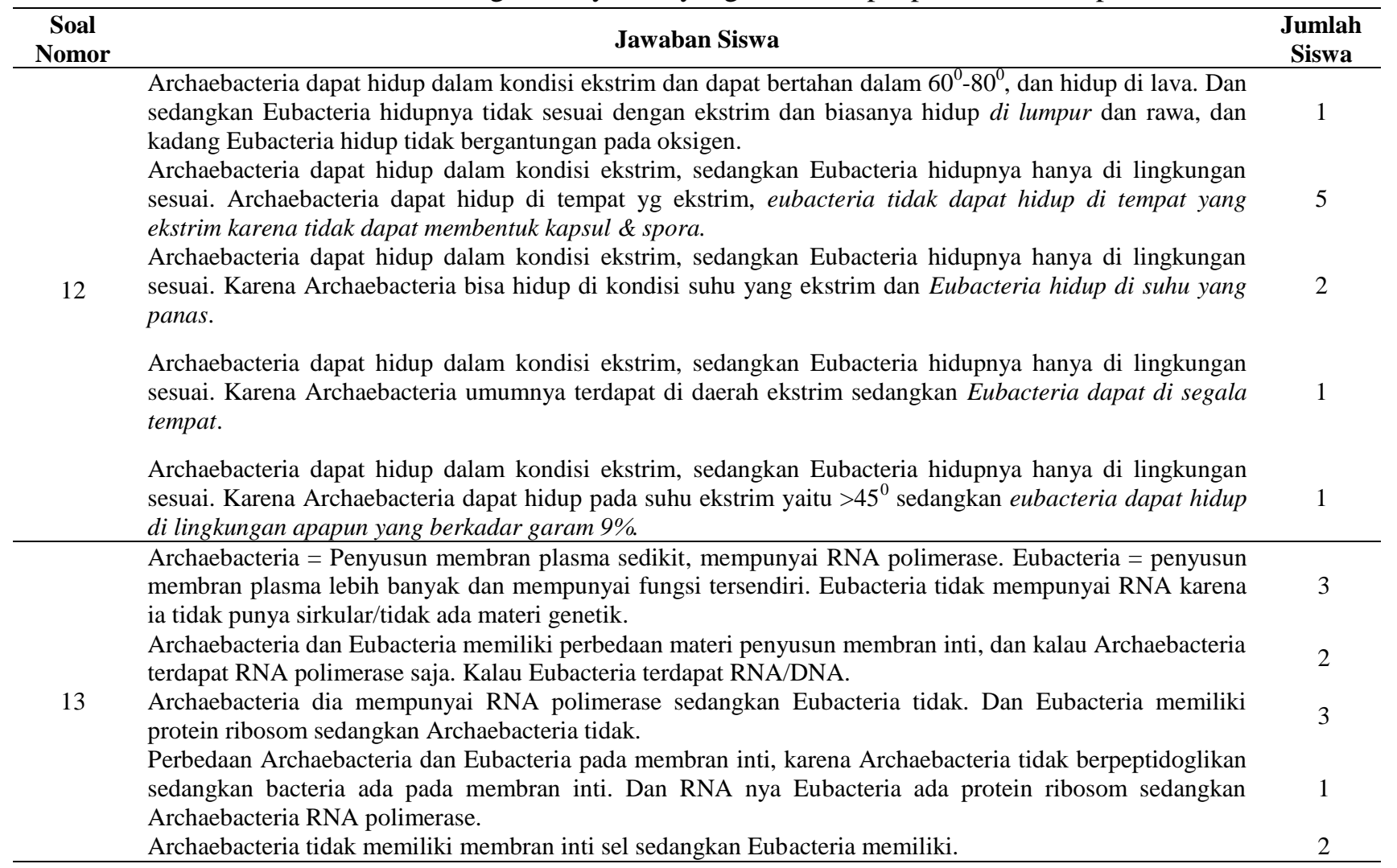


Butir soal nomor 11 berisi indikator mengenai perbedaan ciri bakteri dengan ganggang biru atau Cyanobacteria. Persentase siswa yang jawabannya termasuk kategori salah paham pada butir ini sebanyak $11 \%$. Pernyataan siswa yang miskonsepsi memberikan alasan bahwa "Perbedaan bakteri dengan ganggang biru yaitu dalam hal sifat simbiosisnya". Bakteri dapat bersimbiosis, karena bakteri bisa bersifat menguntungkan juga bisa merugikan sebagai parasit, Lain halnya dengan bakteri kelompok ganggang biru tidak dapat bersimbiosis. Berdasarkan buku Biologi, Cyanobacteria merupakan organisme bakteri yang fotoautotrof, karena mengandung pigmen fotosintetik (Karmana, 2013). Beberapa Cyanobacteria melakukan simbiosis contohnya simbiosis dengan jamur dengan membentuk lumut kerak atau lichen (Widayati, 2009).

\section{Subkonsep Ciri dan Karakteristik Archaebac- teria}

Subkonsep 6 hanya diwakili oleh butir nomor 12 dan 13. Persentase dari kategori miskonsepsi siswa pada subkonsep ini yaitu, 20\%. Adapun pernyataan yang memberikan kategori miskonsepsipada Tabel 8.

Pada butir soal nomor 12, persentase miskonsepsi yakni sebesar 14\%. Pada indikator soal ini, siswa harus dapat membedakan karakteristik Archaebacteria dan Eubacteria berdasarkan tempat hidupnya. Siswa yang miskonsepsi sebagian besar memberikan pernyataan yang benar mengenai perbedaan tempat hidup antara Archaebacteria dan Eubacteria, namun alasannya tidak sesuai dengan konsepnya. Sebagian besar siswa memberikan alasan bahwa "Archaebacteria dapat hidup di tempat yang ekstrim, karena dapat membentuk kapsul dan spora, sedangkan Eubacteria tidak demikian".

Menurut konsep Biologi, Archaebacteria dapat hidup di tempat yang ekstrim, karena kemampuannya dalam beradaptasi dengan lingkungan ekstrim dan memanfaatkan kondisi ekstrim untuk melakukan metabolisme tubuh (Suparno, 2005). Sedangkan bakteri yang dapat membentuk kapsul dan spora adalah bakteri jenis tertentu dari kelompok Eubacteria (Talaro, 2008).

\section{Subkonsep Peranan Positif dan Negatif Organisme Prokariotik}

Butir soal pada subkonsep ketujuh seluruhnya memiliki persentase jawaban miskonsepsi yang tinggi dimana melebihi $10 \%$. Subkonsep ini diwakili oleh indikator pada butir soal 14, 15, 16, dan 17. Kategori jawaban miskonsepsi siswa pada semua butir soal dalam subkonsep ini termasuk bentuk miskonsepsi utuh.

Indikator butir soal nomor 14 yaitu mengenai keberadaan dan peran bakteri pada tubuh manusia. Butir ini memiliki persentase miskonsepsi siswa sebesar $13 \%$. Kalimat jawaban siswa yang termasuk miskonsepsi yaitu bakteri pada tubuh manusia hanya ada di saluran pencernaan saja. Sedangkan kajian teori bakteri ada pada tubuh manusia hampir di setiap bagian tubuh, yaitu di kulit, saluran pencernaan, saluran pernafasan, saluran urin dan saluran reproduksi (Strelkauskas, et. al., 2009).

Tabel 9. Alasan Siswa sebagai Pernyataan yang Miskonsepsi pada Subkonsep Ketujuh

\begin{tabular}{|c|c|c|}
\hline $\begin{array}{c}\text { No } \\
\text { Soal }\end{array}$ & Jawaban Siswa & $\begin{array}{c}\text { Jumlah } \\
\text { Siswa }\end{array}$ \\
\hline \multirow{3}{*}{14} & $\begin{array}{l}\text { Bakteri hanya ada pada proses pencernaan manusia karena bakteri memakan nutrisi makanan dari } \\
\text { manusia yang dimakan. }\end{array}$ & 6 \\
\hline & $\begin{array}{l}\text { Jenis spesies bakteri pada setiap manusia sama karena semua sistem pencernaan manusia sama dan } \\
\text { bakteri pada sistem pencernaannya pasti sama. }\end{array}$ & 2 \\
\hline & $\begin{array}{l}\text { Penggunaan sabun mandi dapat membersihkan semua bakteri pada permukaan tubuh manusia karna } \\
\text { didalam sabun sudah dicampur dengan enzim Archaebacteria. }\end{array}$ & 1 \\
\hline \multirow{4}{*}{15} & $\begin{array}{l}\text { Jumlah bakteri merugikan lebih banyak dibandingkan dengan bakteri menguntungkan karena bakteri lebih } \\
\text { banyak merugikan manusia misalnya hama tanaman. }\end{array}$ & 1 \\
\hline & $\begin{array}{l}\text { Peran bakteri pada ekosistem hanya sebagai pengurai bangkai organisme karena salah satu sifat bakteri } \\
\text { adalah saprofit yaitu pengurai zat sisa, didalam ekosistem bakteri berperan sebagai pengurai bangkai. }\end{array}$ & 11 \\
\hline & $\begin{array}{l}\text { Jumlah bakteri merugikan lebih banyak dibandingkan dengan bakteri menguntungkan karena bakteri itu } \\
\text { berbahaya/ menyebabkan penyakit, jarang ada bakteri yang menguntungkan. }\end{array}$ & 5 \\
\hline & $\begin{array}{l}\text { Peran bakteri pada ekosistem hanya sebagai pengurai bangkai organisme karena tanpa peranan bakteri } \\
\text { suatu bangkai atau yang lainnya tidak dapat diuraikan tanpa menggunakan bakteri. }\end{array}$ & 1 \\
\hline \multirow{3}{*}{16} & $\begin{array}{l}\text { Hampir semua bakteri yang hidup di dalam tubuh manusia dapat menimbulkan penyakit, karena bakteri } \\
\text { yang merugikan banyak tetapi bakteri yang menguntungkan sedikit/bakteri antibiotik. Jika antibiotik } \\
\text { manusia sedikit dan bakteri jahat banyak automatis manusia tersebut akan sakit karena bakteri jahat } \\
\text { menyerang bakteri antibiotik. }\end{array}$ & 1 \\
\hline & $\begin{array}{l}\text { Penggunaan antiseptik dapat membunuh seluruh bakteri yang ada pada permukaan tubuh manusia } \\
\text { karena antiseptik terbuat dari bakteri yang abnormal. }\end{array}$ & 1 \\
\hline & Semakin sedikit jumlah bakteri yang tinggal dalam tubuh manusia, maka manusia tersebut akan semakin & 1 \\
\hline
\end{tabular}




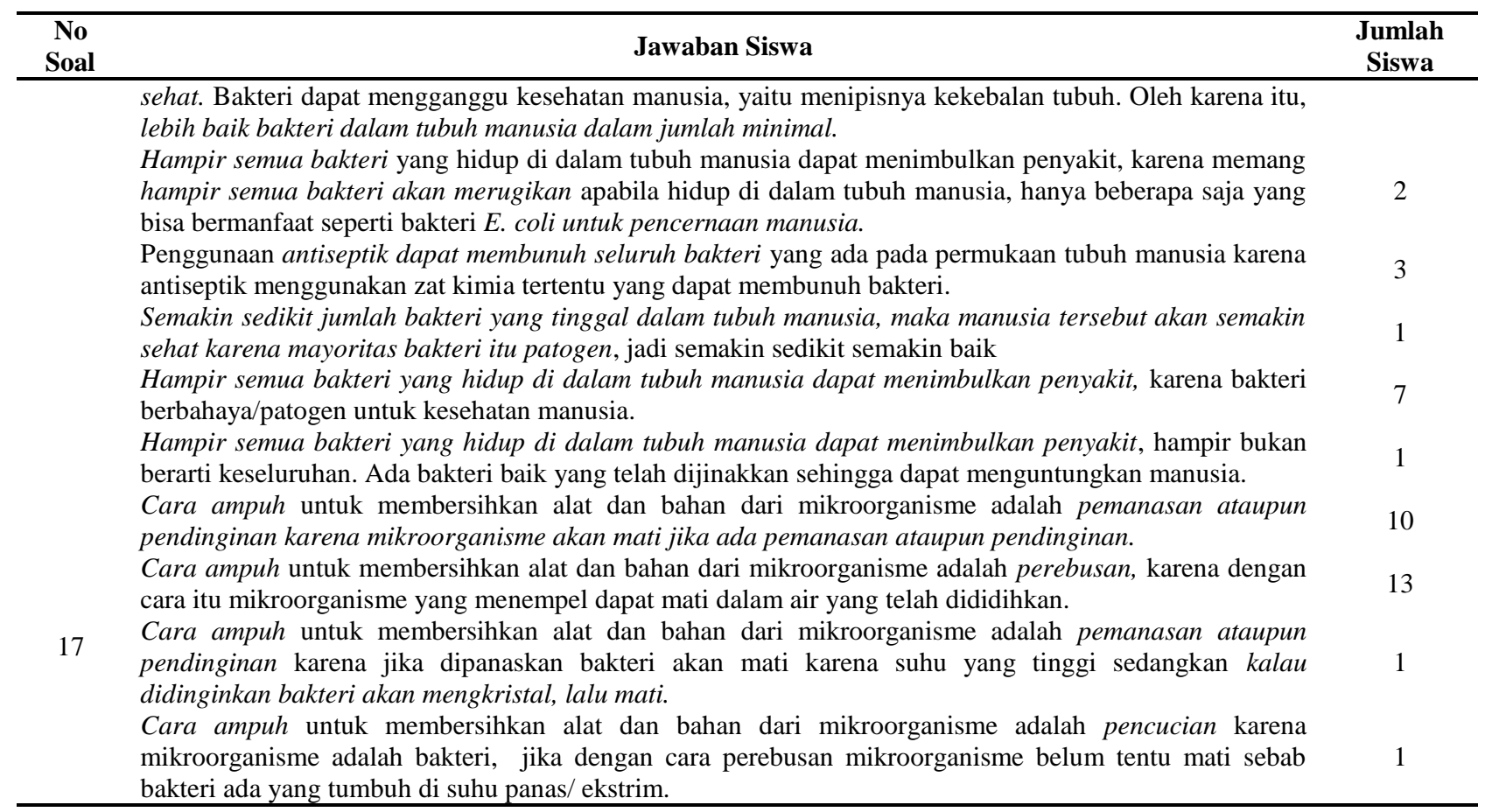

Pada butir soal 15, siswa harus dapat menjelaskan peran bakteri dalam suatu ekosistem. Hasil analisis berbagai jawaban siswa, didapatkan siswa yang salah paham pada indikator ini sebanyak $25 \%$. Pernyataan siswa yang termasuk miskonsepsi memberikan alasan bahwa peran bakteri di ekosistem hanya sebagai pengurai bangkai saja. Ada juga miskonsepsi siswa yang menyatakan bahwa bakteri di ekosistem jauh lebih banyak yang merugikan daripada yang menguntungkan.

Padahal sesungguhnya bakteri memiliki banyak peran, khususnya pada ekosistem. Pada ekosistem, selain sebagai pengurai bakteri juga berperan sebagai produsen. berperan dalam siklus nitrogen, dapat bersimbiosis dengan akar polongpolongan serta simbiosis dengan jamur untuk membentuk lumut kerak, dan lain sebagainya. Bahkan sampai saat ini $90 \%$ bakteri yang telah diketahui bersifat menguntungkan (Widayati, 2009).

Butir soal 16 berisi indikator yang mengharuskan siswa memahami bagaimana peran bakteri terhadap kesehatan manusia. 24\% siswa memberikan jawaban yang mengandung kesalahpaham pada indikator tersebut. Hampir semua jawabannya menyatakan bahwa bakteri dalam tubuh manusia lebih banyak yang merugikan daripada yang menguntungkan. Siswa lain bahkan menganggap bahwa hampir semua bakteri yang ada pada tubuh manusia dapat menyebabkan penyakit.

Sebuah pustaka menyebutkan bahwa lebih dari 50\% sel pada tubuh manusia merupakan sel bakteri, bukan sel tubuh manusia tersebut (Reid \&
Greene, 2013). Hal ini menandakan bahwa tubuh manusia sebetulnya merupakan salah satu habitat yang baik bagi bakteri tertentu. Bakteri juga memegang banyak peranan penting pada proses metabolisme tubuh dan sistem pertahanan tubuh (Reid \& Greene, 2013).

Pada indikator butir soal 17, siswa harus dapat menjelaskan bahwa sterilisasi adalah cara yang ampuh untuk membunuh mikroorganisme. Persentase miskonsepsi siswa pada butir ini adalah yang tertinggi dibandingkan dengan butir lainnya yaitu sebesar 35\%. Berdasarkan hasil tes, siswa yang mengalami salah paham pada indikator soal ini menyatakan bahwa pemanasan dan pendinginan merupakan cara yang ampuh dalam mensterilkan alat atau bahan makanan dari mikroorganisme. Sebagian lain menyatakan bahwa cara yang paling ampuh yaitu dengan perebusan dan pencucian. Konsepsi ini keliru, karena terdapat bakteri sporulasi yang mampu bertahan pada kondisi ekstrim baik berupa suhu ekstrim pada proses pemanasan, perebusan, serta pendinginan, maupun pada zat kimia beracun yang digunakan pada proses pencucian (Talaro, 2008). Salah satu metode untuk membunuh bakteri secara ampuh yaitu dengan sterilisasi. Sterilisasi adalah metode pemusnahan bakteri dengan tujuan mendapatkan kondisi steril, dengan teknik tertentu (Widayati, 2009). Metode ini lebih ampuh karena dapat menghancurkan spora pada bakteri sporulasi.

Ketujuh indikator soal ini, didapatkan berbagai kesalahpahaman siswa mengenai peranan bakteri pada tubuh manusia maupun pada ekosistem. Berdasarkan hasil analisis, dapat dipahami bahwa siswa yang salah paham 
cenderung menganggap bakteri adalah organisme yang kebanyakan merugikan bagi manusia. Konsepsi ini dibentuk siswa dari intuisi pengalaman sehari-hari dan masyarakat di sekitar mereka. Hasil penelitian Tarwoko menyebutkan bahwa miskonsepsi siswa terhadap peranan bakteri dapat disebabkan prakonsepsi yang salah yang sumbernya berasal dari informasi melalui televisi atau pemahahaman masyarakat yang salah terhadap bakteri (Tarwoko, 2005).

\section{PENUTUP}

Temuan yang didapat setelah menelusuri pemahaman siswa pada konsep Archaebacteria dan Eubacteria didapatkan informasi bahwa siswa memiliki nilai miskonsepsi yang sedikit (19\%). Kategori miskonsepsi yang dialami oleh siswa cenderung teridentifikasi pada miskonsepsi utuh. Pernyataan indikator butir soal yang mendominasi nilai miskonsepsi adalah "Usaha manusia yang dilakukan untuk menghindari peran negatif bakteri." dengan anggapan yang salah berupa "Bakteri lebih banyak menimbulkan kerugian daripada keuntungan bagi manusia dan lingkungan. Anggapan ini sebagian besar berasal dari kelompok siswa dengan kemampuan kognitif sedang dan tinggi.

Sedikitnya total persentase miskonsepsi siswa bukan disebabkan pada rendahnya kepahaman siswa terhadap konsep, melainkan dari tingginya ketidakpahaman siswa. Hal ini disebabkan pada proses belajar yang tidak tercapaiannya kebermaknaan. Oleh karena itu, perlu dilakukan penelitian berikutnya untuk menelusuri sumber ketidakpahaman tersebut yang dapat berasal dari siswa, guru, buku teks, maupun strategi mengajar. Hasil dari penelitian ini dan berikutnya

dapat dijadikan refleksi bagi guru dalam pembelajaran biologi selanjutnya dan perguruan tinggi sebagai referensi dalam perbaikan pembelajaran untuk calon guru.

\section{DAFTAR PUSTAKA}

Allen M. 2010. Misconceptions in primary science. New York: Open University Press.

American Institute of Biological Sciences. 2013. "Misconceptions About Microbes". http://www.usc.edu/org/coseewest/Mar26201 1/01MisconceptionsAboutMicrobes.pdf.

Barke HD, Hazari A, Yitbarek S. 2009. Misconceptions in Chemistry. Verlag Berlin Heidelberg: Springer.
Calik M, Ayas A. 2005. A Cross-age Study on the Understanding of Chemical Solutions and Their Components. International Education Journal 6.

Departemen Pendidikan Nasional. 2007. Tes Diagnostik. Jakarta: Direktorat Jenderal Manajemen Pendidikan Dasar dan Menengah, Direktorat Pembinaan Sekolah Menengah Pertama.

Garber, Steven D. 2002. Biology A Self-Teaching and Guide. New Jersey: John Wiley \& Sons, Inc.

Karmana O. 2013. Biologi untuk Kelas X Sekolah Menengah Atas. Jakarta: Grafindo.

Krebs RE. 1999. Scientific development and misconceptions through the ages: a reference guide. USA: Greenwood Press.

Mintzes JJ, Wandersee JH, Novak JD. 2005. Assessing Science Understanding.California: Elsevier Academ ic Press.

Muniri. 2013. "Karakteristik Berpikir Intuitif Siswa dalam Menyelesaikan Masalah Matematika". Makalah disampaikan pada Seminar Nasional Matematika dan Pendidikan Matematika. 9 November 2013. Yogyakarta: FMIPA Universitas Negeri Yogyakarta.

National Science Teachers Association. 2013. Buku Pedoman Guru Biologi Edisi ke-4. Jakarta Barat. PT. Indeks.

Pujiyanto S. 2012. Menjelajah Dunia Biologi. Jakarta: Platinum.

Reid A, Greene S. 2013. Human Microbiome. American Academy of Microbiology: Washington DC.

Sabri MA. 2007. Psikologi Pendidikan. Jakarta: Pedoman Ilmu Jaya.

Strelkauskas A, Strelkauskas J. 2014. Microbiology: A Clinical Approach. http://www.garlandscie nce.com/res/pdf/9780815365143_ch05.pdf.

Sukmadinata NS. 2012. Metode Penelitian Pendidikan. Bandung: PT Remaja Rosdakarya.

Suparno P. 2005. Miskonsepsi dan Perubahan Konsep dalam Pendidikan Fisika. Jakarta: PT Grasindo.

Suparno P. 1997. Filsafat Konstruktivisme dalam Pendidikan. Yogyakarta: Kanisius. 
Talaro KP. 2008. Foundations in Microbiology. New York: Mc-Graw Hill.

Tarwoko E. 2005. "Reduksi miskonsepsi bakteri siswa-siswa SMA Negeri 1 Sambung Macan dengan pembelajaran modul dan lembar kerja siswa". Tesis pada Pascasarjana Universitas Sebelas Maret, Surakarta. tidak dipublikasikan.

Tekkaya C. 2002. Misconceptions as Barrier to Understanding Biology. Journal of Hacattepe Universitesi Egitim Fakultasi Dergisi 23: 259-266.
Widdiharto R. 2008. Diagnosis Kesulitan Belajar Matematika SMP dan Alternatif Proses Remidinya. Yogyakarta: Depdiknas, Pusat Pengembangan dan Pemberdayaan Pendidik dan Tenaga Kependidikan Matematika.

Widiyati S, Rochmah SN, Zubedi. 2009. Biologi SMA/MA. Jakarta: Pusat Perbukuan, Departemen Pendidikan Nasional.

Zulfiani, Permana I, Feronika T. 2009. Strategi Pembelajaran Sains. Jakarta: Lembaga Penelitian UIN Jakarta. 